\title{
Seasonal Variation of Criteria Pollutant in an Urban Coastal Environment: Kuala Terengganu
}

\author{
Si Yuen Fong, Marzuki Ismail ${ }^{*}$, Samsuri Abdullah \\ School of Marine Science and Environment, Universiti Malaysia Terengganu, Kuala Terengganu, Malaysia
}

\begin{abstract}
The aim of this study are (i) to determine the yearly and monsoonal variations of the criteria pollutants in Kuala Terengganu, (ii) identify the influences of the meteorological factors and other minor criteria pollutants that impose on the concentration of the most significant criteria pollutant using Principal Component Analysis (PCA). The hourly data for the criteria pollutants $\left(\mathrm{PM}_{10}, \mathrm{CO}, \mathrm{O}_{3}, \mathrm{NO}_{2}\right.$, and $\left.\mathrm{SO}_{2}\right)$ and meteorological factors (temperature, relative humidity, windspeed) for the duration of 10 years procured from the Department of Environment, Malaysia were analyzed. $\mathrm{PM}_{10}$ is the only pollutant that frequently recorded concentrations exceeding the MAAQG in the length of the year 2001 to 2010 and the criteria pollutants reported differ significantly between the monsoon seasons. PCA showed that sources contributing to the most significant criteria pollutant $\left(\mathrm{PM}_{10}\right)$ are meteorological factor influences and industrial emissions
\end{abstract}

\section{Introduction}

More than two-thirds of the world's largest cities are located on the coastline and around half of the human population inhabits within $150 \mathrm{~km}$ of a coast. The rapid development of the coastal cities also causes the gradual air quality degradation which in turn increases the health threat to both human and environment. Various studies have been done over the years to identify the attribution of air pollutions towards people's health and the adverse effects brought forward to the environment [1-4].

In order to categorized the health impact of air pollution, United States Environmental Protection Agency (US EPA) has established the Air Quality Index (AQI) to signify the air quality in a particular region in which the index is mainly focused on the measurement of five major air pollutants, which are carbon monoxide (CO), sulphur dioxide $\left(\mathrm{SO}_{2}\right)$, nitrogen dioxide $\left(\mathrm{NO}_{2}\right)$, particulate matter $(\mathrm{PM})$ and ozone $\left(\mathrm{O}_{3}\right)$ [5]. In Malaysia, there is a similar system to indicate the overall quality of air called Air Pollution Index (API), [6]. Based on the Environmental Quality Report of the year 2013, the concentration of the criteria pollutants often exceeds the Malaysia Ambient Air Quality Guidelines and the most prominent pollutant that frequently causes the moderate air quality days in Malaysia is particulate matter. Motor vehicles, abrasion of tires and brakes, marine aerosols, agricultural activities and even cooking contributes to a significant amount of PM, biomass burnings produces $\mathrm{CO}$, whereas industrial activities and power plants are the major contributors of aerosols such as $\mathrm{SO}_{2}, \mathrm{NO}_{2}$ and $\mathrm{O}_{3}$ forming pollutants [7]-[10]. The ambient air quality

\footnotetext{
* Corresponding author: marzuki@umt.edu.my
}

management policies are the product of series of complex and conservative processes, which include the air quality monitoring, preparation of emission inventory and control strategies delineation, and long-term compliance monitoring [11]. In Malaysia, the air quality status monitoring was done under the responsibility of the Department of Environment (DOE).

Air quality is often influenced by three major factors, i.e. emission sources, prevailing meteorological factors and terrain morphology [12]. The study was conducted in Kuala Terengganu, one of the capital cities on the East Coast of Peninsular Malaysia, which is less than $2 \mathrm{~km}$ from the shoreline. As the study area is closely associated with the sea, the sources of air pollution originate from offshore as well as onshore with a flat terrain. Kuala Terengganu experienced two major monsoons annually and two inter-monsoons in between [13]. This coastal urban area has been developing rapidly in the past years and has achieved the urbanization level of $59.1 \%$ in the year 2010 [14] and thus further exposing the residents to the bearings of air pollution. To assess the efficacy of the control and preventive regulations of the air pollution, the trend, and status of the air quality must be studied thoroughly. The aim of this study is to interpret the variations of the criteria pollutant in Kuala Terengganu and determine the seasonal changes of the criteria pollutants. The influences of the meteorological factors and other minor criteria pollutants that impose on the concentration of the most significant criteria pollutant, which in our case is $\mathrm{PM}_{10}$, will also be identified. The source apportionment analysis may provide insight for the identification of the pollution 
emission sources and the amount of impact inflicted to the air pollution.

\section{Methodology}

\subsection{Study Area and Data Collection}

Kuala Terengganu is the capital city of Terengganu state. It is located on the East Coast of the Peninsular Malaysia with less than $2 \mathrm{~km}$ from the coastline. There are a total number of three air quality monitoring stations in the Terengganu state, each located in a different district, managed by the Department of Environment. The air quality monitoring station chosen for this study is situated in the capital of Terengganu state which is located at Sekolah Men. Keb. Chabang Tiga (N05'18.487", E103 $07.226^{\prime \prime}$ ) (Figure 1). The topography of the area is characterized by lowlands due to the proximity to the coastline.

The data used for the analysis were acquired from the Department of Environment (DOE). The hourly data for the criteria pollutants $\left(\mathrm{PM}_{10}, \mathrm{CO}, \mathrm{O}_{3}, \mathrm{NO}_{2}\right.$, and $\left.\mathrm{SO}_{2}\right)$ and meteorological factors (temperature, relative humidity, windspeed) for the duration of 10 years starting from January 2001 to December 2010 were procured.

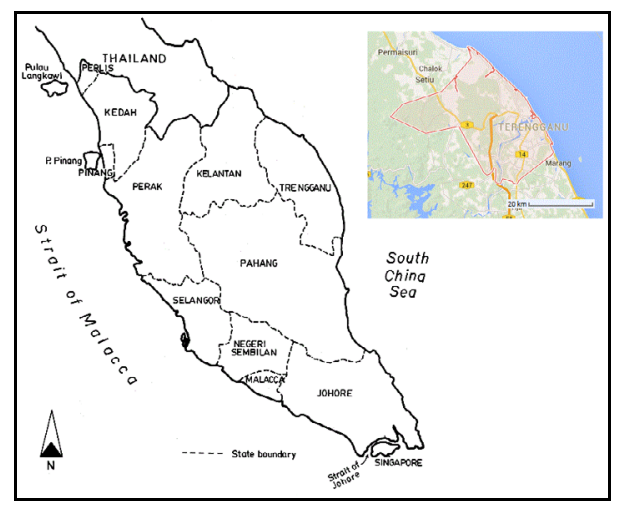

Figure 1. Location of study area

\subsection{Statistical Analysis}

The pollutant concentration and meteorological factor trends along the 10 years of data were sorted and calculated by using Microsoft Excel ${ }^{\circledR}$. The data were the depicted in monthly average trends. Statistical analysis was executed on the data set to extract descriptive information. Analysis of Variance, Multiple Range Test, Kruskal-Wallis test and Standard Kurtosis Test were done to test the significance amongst the means of the data, to determine which mean is significantly different from each other, identify the outliers and test for normality. The missing values during the study period were omitted in the statistical computations.

\subsection{Principal Component Analysis}

Principal Component Analysis (PCA) is a source identification method that enables us to certify that the variables were ideally correlated with one sole component only without correlating with other component and produce a new set of variables called principal component (PCs) [15], [16]. The number of principal components will be less than or equals to the original variables. The most significant Pc allow us to determine the relationship between the variables and the dataset, thus deducing the possible sources.

\section{Results and Discussion}

\subsection{Yearly Variation of Criteria Pollutants}

The daily averaged concentration for the criteria pollutants, $\mathrm{PM}_{10}, \mathrm{CO}, \mathrm{O}_{3}, \mathrm{NO}_{2}$ and $\mathrm{SO}_{2}$ recorded in the study area are $52.03 \mu \mathrm{g} / \mathrm{m}^{3}\left(5-400 \mu \mathrm{g} / \mathrm{m}^{3}\right), 0.456 \mathrm{ppm}$ (0.000 - $4.850 \mathrm{ppm}), 0.014 \mathrm{ppm}(0.000-0.080 \mathrm{ppm})$, $0.005 \mathrm{ppm}(0.000-0.033 \mathrm{ppm})$ and $0.001 \mathrm{ppm}(0.000-$ $0.020 \mathrm{ppm}$ ) respectively (Table 1). The highest concentration for $\mathrm{PM}_{10}$ was recorded in January 2002. Although Malaysia is experiencing moderate Northeast monsoon, the Northern ASEAN regions were dominated by dry weather conditions where hotspots were detected in Cambodia, Laos PDR, Myanmar, and Thailand due to the El Nino occurrence. Prevailing North-easterly winds brings over smoke and haze from the northern region to the study area [17].

As we can see in Table 2, the annual variations for the criteria pollutants does not fluctuates much in the past 10 years except for $\mathrm{PM}_{10}$. The concentration for $\mathrm{PM}_{10}$ exceeded the MAAQG of $50 \mu \mathrm{g} / \mathrm{m}^{3}$ in eight out of the ten years whereas other criteria pollutants recorded concentrations way below the MAAQG (Table 2). As the study area is an urban coastal environment, the main contributors of $\mathrm{PM}_{10}$ are not only local sources such as traffic aerosols, biomass burning, soil dust, vehicle exhaust and secondary aerosols but a high amount of the concentration were originating from the sea sprays [18], [19].

The trend of the monthly average concentration of the criteria pollutants was illustrated in Figure 2. $\mathrm{PM}_{10}$ and $\mathrm{O}_{3}$ have the highest concentration in December and January while $\mathrm{NO}_{2}$ and $\mathrm{SO}_{2}$ recorded higher concentrations in May, and July. As for CO, two peaks that fall in month February and August were noticed.

Table 1. Summary of criteria pollutants data in Kuala Terengganu (Year 2001-2010)

\begin{tabular}{|l|c|c|c|c|}
\hline \multicolumn{1}{|c|}{ Parameters } & Average & $\begin{array}{c}\text { Standard } \\
\text { Deviation }\end{array}$ & Minimum & Maximum \\
\hline $\mathrm{PM}_{10}\left(\mu \mathrm{g} / \mathrm{m}^{3}\right)$ & 52.0 & 24.9 & 5.0 & 400.0 \\
\hline $\mathrm{CO}(\mathrm{ppm})$ & 0.456 & 0.310 & 0.000 & 3.850 \\
\hline $\mathrm{O}_{3}(\mathrm{ppm})$ & 0.014 & 0.012 & 0.000 & 0.080 \\
\hline $\mathrm{NO}_{2}(\mathrm{ppm})$ & 0.005 & 0.004 & 0.000 & 0.033 \\
\hline $\mathrm{SO}_{2}(\mathrm{ppm})$ & 0.001 & 0.001 & 0.000 & 0.020 \\
\hline
\end{tabular}


Table 2. Annual averaging values of criteria pollutant (Year 2001 -2010)

\begin{tabular}{|c|c|c|c|c|c|c|c|c|c|c|}
\hline \multirow{2}{*}{ Year } & \multicolumn{2}{|c|}{$\mathbf{P M}_{\mathbf{1 0}}\left(\boldsymbol{\mu g} / \mathbf{m}^{\mathbf{3}}\right)$} & \multicolumn{2}{|c|}{ CO (ppm) } & \multicolumn{2}{|c|}{$\mathbf{O}_{\mathbf{3}}(\mathbf{p p m})$} & \multicolumn{2}{c|}{ NO$_{2}(\mathbf{p p m})$} & \multicolumn{2}{c|}{ SO $_{2}(\mathbf{p p m})$} \\
\cline { 2 - 13 } & Mean & $\begin{array}{c}\text { Std } \\
\text { Dev* }\end{array}$ & Mean & $\begin{array}{c}\text { Std } \\
\text { Dev }\end{array}$ & Mean & $\begin{array}{c}\text { Std } \\
\text { Dev }\end{array}$ & Mean & $\begin{array}{c}\text { Std } \\
\text { Dev }\end{array}$ & Mean & $\begin{array}{c}\text { Std } \\
\text { Dev }\end{array}$ \\
\hline 2001 & 57.1 & 24.6 & 0.427 & 0.321 & 0.015 & 0.011 & 0.005 & 0.004 & 0.001 & 0.0009 \\
\hline 2002 & 54.4 & 24.5 & 0.434 & 0.323 & 0.014 & 0.011 & 0.005 & 0.004 & 0.000 & 0.0009 \\
\hline 2003 & 51.6 & 24.7 & 0.462 & 0.328 & 0.015 & 0.012 & 0.005 & 0.004 & 0.001 & 0.0008 \\
\hline 2004 & 56.1 & 27.4 & 0.477 & 0.305 & 0.017 & 0.013 & 0.006 & 0.004 & 0.001 & 0.0011 \\
\hline 2005 & 51.9 & 25.6 & 0.471 & 0.334 & 0.014 & 0.012 & 0.006 & 0.004 & 0.001 & 0.0009 \\
\hline 2006 & 53.0 & 26.3 & 0.462 & 0.304 & 0.014 & 0.011 & 0.006 & 0.004 & 0.001 & 0.0011 \\
\hline 2007 & 45.4 & 24.0 & 0.455 & 0.275 & 0.014 & 0.011 & 0.006 & 0.004 & 0.001 & 0.0010 \\
\hline 2008 & 50.8 & 22.4 & 0.394 & 0.264 & 0.015 & 0.011 & 0.006 & 0.004 & 0.001 & 0.0010 \\
\hline 2009 & 50.8 & 25.1 & 0.495 & 0.325 & 0.014 & 0.011 & 0.005 & 0.004 & 0.001 & 0.0009 \\
\hline 2010 & 49.3 & 21.1 & 0.489 & 0.301 & 0.012 & 0.009 & 0.005 & 0.003 & 0.001 & 0.0008 \\
\hline & $24 \mathrm{hr}$ & $1 \mathrm{yr}$ & $1 \mathrm{hr}$ & $8 \mathrm{hr}$ & $1 \mathrm{hr}$ & $8 \mathrm{hr}$ & $1 \mathrm{hr}$ & $24 \mathrm{hr}$ & $1 \mathrm{hr}$ & $24 \mathrm{hr}$ \\
\hline MAAQG $^{\mathrm{a}}$ & 150 & 50 & 30 & 9.0 & 0.1 & 0.06 & 0.17 & 0.04 & 0.13 & 0.04 \\
\hline WHO $^{\mathrm{b}}$ & 50 & 40 & - & - & - & 0.047 & 0.10 & - & - & - \\
\hline EC $^{\text {c }}$ & 50 & 40 & - & 0.008 & - & 0.057 & 0.10 & - & 0.124 & 0.044 \\
\hline
\end{tabular}

*Standard Deviation

${ }^{a}$ Malaysian Ambient Air Quality Guidelines

${ }^{\mathrm{b}}$ World Health Organization Air Quality Guidelines

${ }^{\mathrm{c}}$ European Commission Air Quality Standards
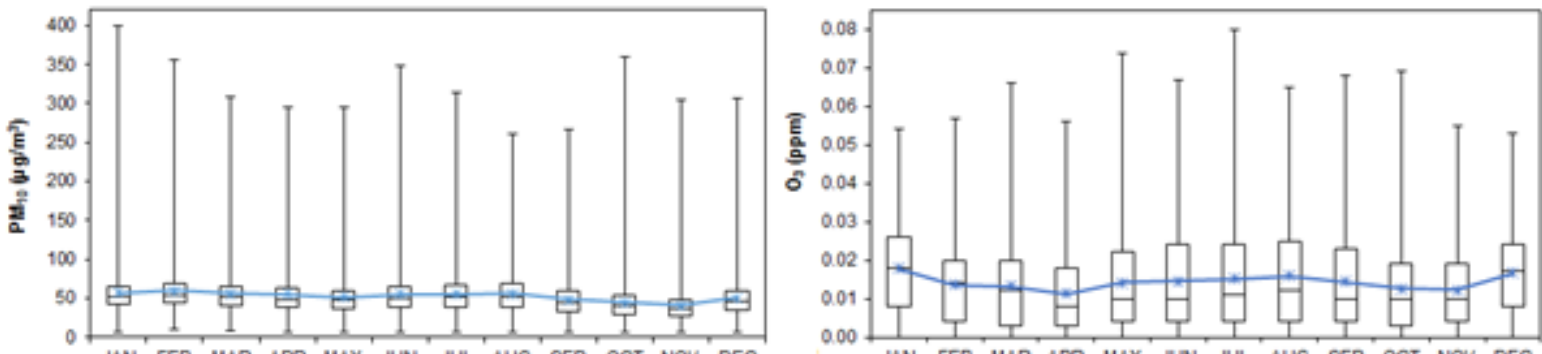

IAN FEB MAR APR MAY JUN JUL AUG SEP OCT NOV DEC

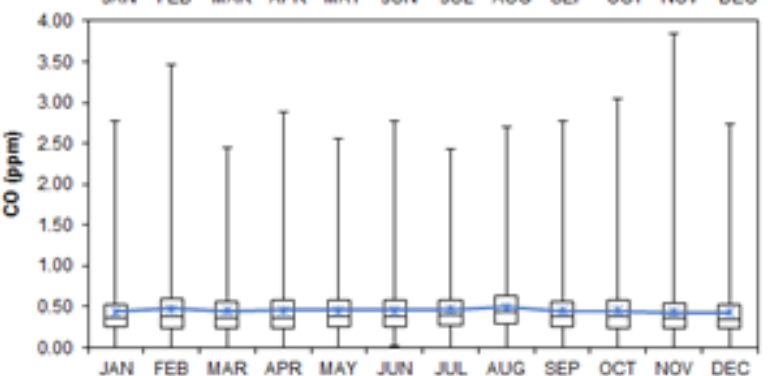

JAN FEB MAR APR MAY JUN JUL AUG SEP OCT NOV DEC
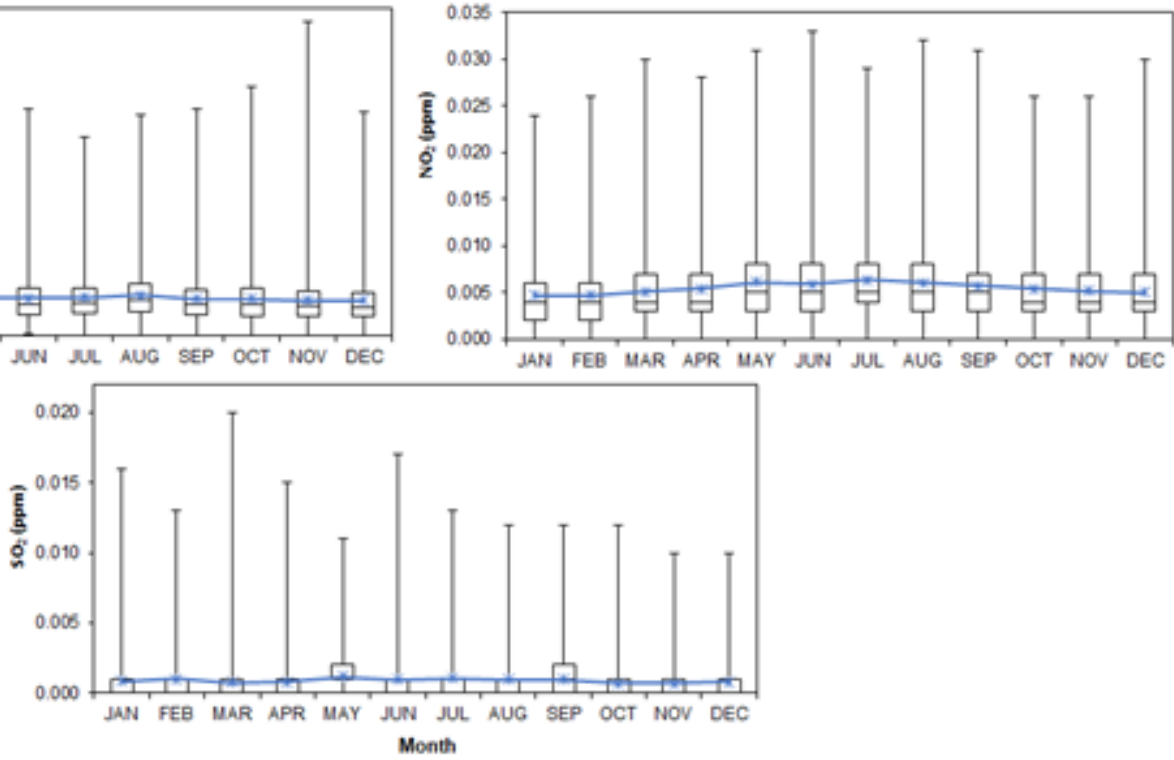

Figure 2. Monthly average of criteria pollutant (year 2001-2010) 

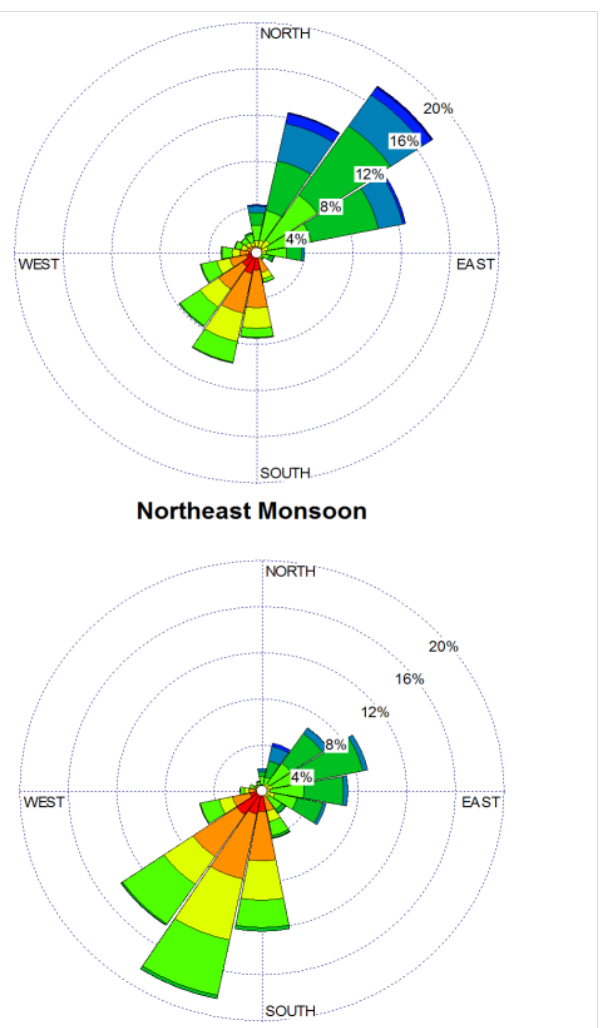

April Inter-monsoon

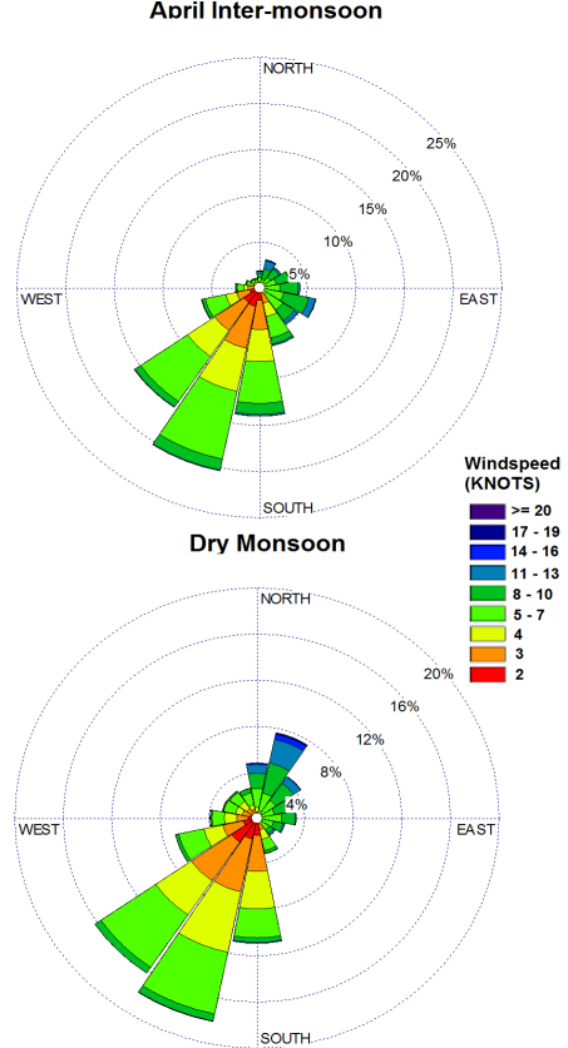

October Inter-monsoon

Figure 3. Windrose (a) Northeast monsoon (b) April intermonsoon (c) Southwest monsoon and (d) October inter-monsoon

\subsection{Monsoonal Variation}

There are two major monsoons in Malaysia and two intermonsoons in between. The wet monsoon, also known as the Northeast monsoon (NEM) blows from November to March, followed by the April inter-monsoon (AIM), where the northeasterly winds change to southwesterly winds. The dry monsoon, otherwise the Southwest monsoon (SWM) starts from May and ends in September and replace by the October inter-monsoon (OIM) [13], [20].

The wind rose of hourly wind direction, and windspeed for the four monsoons was illustrated in Figure 3. The wind is strongest during the NEM, and the wind originates mostly from Northeast whereas, in AIM, the dominant wind direction gradually changes to Southwest and last until the OIM. The southwesterly wind during the SWM is generally milder but happens more frequently [21].

The criteria pollutants recorded at the study areas differ significantly between the distinctive monsoons as the pvalue for each pollutant are less than 0.05 at the $95.0 \%$ confidence level (Table 3). This is mostly due to the distinguishable meteorological conditions portrays by the different monsoons. The NEM is characterized by heavy rainfall and strong winds while the SWM are accompanied by cloudless skies and drier weather.

To identify the differences between the monsoons, the Multiple Range Test was performed, and the results were tabulated in Table 4. The lower and upper limits of the average of the concentration of the criteria pollutants for the different monsoons were calculated, and the range of the limits was referred as intervals. These intervals are calculated based on the Fisher's least significant difference (LSD) procedure, and the overlapping intervals signify similar means, which denotes that there is no significant difference between the two monsoons.

Referring to Table 4 , the average concentration of $\mathrm{PM}_{10}$ is $52.1 \mu \mathrm{g} / \mathrm{m}^{3}$ for NEM, $53.1 \mu \mathrm{g} / \mathrm{m}^{3}$ for SWM and 49.2 $\mu \mathrm{g} / \mathrm{m}^{3}$ for the inter-monsoons. As for the $\mathrm{NO}_{2}$, the reported average concentration were $0.0060 \mathrm{ppm}, 0.0054 \mathrm{ppm}$ and $0.0049 \mathrm{ppm}$ for SWM, inter-monsoons, and NEM respectively whereas for $\mathrm{SO}_{2}$, the highest average concentration were $0.0010 \mathrm{ppm}$ for SWM, followed by $0.0008 \mathrm{ppm}$ and $0.0007 \mathrm{ppm}$ for NEM and inter-monsoons accordingly. The concentration of $\mathrm{PM}_{10}, \mathrm{NO}_{2}$ and $\mathrm{SO}_{2}$ are higher during the SWM. This could be due to the stable drier meteorological conditions that cause hindrance to dispersion and removal of the pollutants from the atmosphere $[22,23]$.

The highest average concentration of $\mathrm{CO}$ was recorded in the SWM, followed by the inter-monsoons and NEM with the values of $0.467 \mathrm{ppm}, 0.454 \mathrm{ppm}$ and $0.446 \mathrm{ppm}$ respectively. The intervals for the three different monsoon categories do not overlap thus, indicating that all three monsoons have statistically significant different concentrations of $\mathrm{CO}$. The primary sources of $\mathrm{CO}$ are incomplete combustion of fossil fuels and biomass burning $[24,25]$. Hydroxyl groups function as sinks to remove CO from the atmosphere and due to the substantial deposition phenomena during the NEM, hydroxyl groups are available in 
abundance thus, pairing up with the $\mathrm{CO}$ in the air and produces $\mathrm{CO}_{2}[25,26]$.

Of all the criteria pollutants, only $\mathrm{O}_{3}$ show an overlapping interval in the NEM and SWM. The average concentration of $\mathrm{O}_{3}$ are highest in SWM, with the value of $0.01480 \mathrm{ppm}$, coming next is $0.01478 \mathrm{ppm}$ in NEM and $0.01201 \mathrm{ppm}$ in the inter-monsoons.

\subsection{Pincipal Component Analysis of Particulate Matter Concentration}

The most significant pollutant observed in the study area is $\mathrm{PM}_{10}$, and thus, the PCA of $\mathrm{PM}_{10}$ with other criteria pollutants and meteorological factors were performed for the two main monsoons, the NEM and SWM in order to further understand the dynamics and influences on the $\mathrm{PM}_{10}$ concentration.

To execute the PCA, the individual variable and the set of variables must obtain the Kaiser-Meyer-Olkin
(KMO) of Sampling Adequacy value of greater than 0.50 and the probability associated with Bartlett's Test of Sphericity be less than the level of significance [27]. The KMO value for the NEM and SWM dataset was 0.822 and 0.753 respectively while the probability associated with the Bartlett test is $<0.001$ for both datasets, which satisfies the basic requirement for the PCA.

The list of eigenvalues associated with each linear component before extraction, after extraction and after rotation for the NEM and SWM is presented in Table 5. Before extraction, 8 linear components are identified within both data sets. The eigenvalues associated with each factor represent the variance explained by the particular linear component and also displays their eigenvalue in terms of the percentage of variance explained. All factors with the eigenvalues greater than 1 were extracted but for our case, component 3 for both monsoons has eigenvalue closed to 1 , hence, the third component were taken into consideration.

Table 3. Analysis of variance if criteria pollutants

\begin{tabular}{|l|l|c|c|c|c|c|}
\hline \multicolumn{1}{|c|}{ Parameters } & \multicolumn{1}{|c|}{ Comparison } & $\begin{array}{c}\text { Sum of } \\
\text { squares }\end{array}$ & $\begin{array}{c}\text { Degree of } \\
\text { freedom (df) }\end{array}$ & $\begin{array}{c}\text { Mean } \\
\text { square }\end{array}$ & F-Value & Significance \\
\hline $\mathrm{PM}_{10}\left(\mu \mathrm{g} / \mathrm{m}^{3}\right)$ & Between groups & 151656 & 2 & 75827.80 & 123.10 & 0.000 \\
\hline & Within groups & 53130600 & 86250 & 616.006 & & \\
\hline & Total (Corr.) & 53282200 & 86252 & & & \\
\hline & Between groups & 7.370 & 2 & 3.685 & 38.320 & 0.000 \\
\hline & Within groups & 7634.900 & 79388 & 0.096 & & \\
\hline & Total (Corr.) & 7642.27 & 79390 & & & \\
\hline & Between groups & 0.09 & 2 & 0.04 & 328.00 & 0.000 \\
\hline & Within groups & 10.702 & 80989 & 0.000 & & \\
\hline & Total (Corr.) & 10.788 & 80991 & & & \\
\hline $\mathrm{NO}_{2}(\mathrm{ppm})$ & Between groups & 0.020 & 2 & 0.010 & 684.430 & 0.000 \\
\hline & Within groups & 1.211 & 81589 & 0.000 & & \\
\hline & Total (Corr.) & 1.23142 & 81591 & & & \\
\hline $\mathrm{SO}_{2}(\mathrm{ppm})$ & Between groups & 0.00 & 2 & 0.00 & 572.04 & 0.000 \\
\hline & Within groups & 0.072 & 77501 & 0.000 & & \\
\hline & Total (Corr.) & 0.073 & 77503 & & & \\
\hline
\end{tabular}

Table 4. Multiple Range Test: Average and Least Significance Difference (LSD) Intervals for criteria pollutants in different monsoons

\begin{tabular}{|l|c|c|c|}
\hline \multicolumn{1}{|c|}{ Parameters } & Northeast Monsoon & Inter-monsoons & Southwest Monsoon \\
\hline $\mathrm{PM}_{10}\left(\mu \mathrm{g} / \mathrm{m}^{3}\right)$ & $52.1(51.9-52.3)$ & $49.2(48.9-49.5)$ & $53.1(52.9-53.2)$ \\
\hline $\mathrm{CO}(\mathrm{ppm})$ & $0.446(0.444-0.449)$ & $0.454(0.450-0.458)$ & $0.467(0.465-0.470)$ \\
\hline $\mathrm{O}_{3}(\mathrm{ppm})$ & $0.01478\left( \pm 1.7 \times 10^{-4}\right)$ & $0.01201\left( \pm 2.7 \times 10^{-4}\right)$ & $0.01480\left( \pm 1.7 \times 10^{-4}\right)$ \\
\hline $\mathrm{NO}_{2}(\mathrm{ppm})$ & $0.0049\left( \pm 5.8 \times 10^{-5}\right)$ & $0.0054\left( \pm 9.1 \times 10^{-5}\right)$ & $0.0060\left( \pm 5.7 \times 10^{-5}\right)$ \\
\hline $\mathrm{SO}_{2}(\mathrm{ppm})$ & $0.0008\left( \pm 1.5 \times 10^{-5}\right)$ & $0.0007\left( \pm 2.4 \times 10^{-5}\right)$ & $0.0010\left( \pm 1.5 \times 10^{-5}\right)$ \\
\hline
\end{tabular}


Table 5. Total Variance and Eigenvalues for (a) NEM and (b) SWM

Total Variance and Eigenvalues of NEM

\begin{tabular}{|c|c|c|c|c|c|c|c|c|c|}
\hline \multirow{2}{*}{ Component } & \multicolumn{3}{|c|}{ Initial Eigenvalues } & \multicolumn{3}{c|}{$\begin{array}{c}\text { Extraction Sums of Squared } \\
\text { Loadings }\end{array}$} & \multicolumn{3}{|c|}{ Rotation Sums of Squared Loadings } \\
\cline { 2 - 9 } & Total & $\begin{array}{c}\text { \% of } \\
\text { Variance }\end{array}$ & Cumulative \% & Total & $\begin{array}{c}\text { \% of } \\
\text { Variance }\end{array}$ & Cumulative \% & Total & $\begin{array}{c}\% \text { of } \\
\text { Variance }\end{array}$ & Cumulative \% \\
\hline 1 & 3.684 & 52.632 & 52.632 & 3.684 & 52.632 & 52.632 & 2.778 & 39.686 & 39.686 \\
2 & 1.146 & 16.368 & 68.999 & 1.146 & 16.368 & 68.999 & 1.851 & 26.446 & 66.132 \\
3 & .821 & 11.730 & 80.729 & .821 & 11.730 & 80.729 & 1.022 & 14.597 & 80.729 \\
4 & .494 & 7.063 & 87.792 & & & & & & \\
5 & .302 & 4.321 & 92.113 & & & & & & \\
6 & .287 & 4.094 & 96.207 & & & & & & \\
7 & .266 & 3.793 & 100.000 & & & & & & \\
\hline
\end{tabular}

Total Variance and Eigenvalues of SWM

\begin{tabular}{|c|c|c|c|c|c|c|c|c|c|}
\hline \multirow{2}{*}{ Component } & \multicolumn{3}{|c|}{ Initial Eigenvalues } & \multicolumn{3}{c|}{$\begin{array}{c}\text { Extraction Sums of Squared } \\
\text { Loadings }\end{array}$} & \multicolumn{3}{|c|}{ Rotation Sums of Squared Loadings } \\
\cline { 2 - 10 } & Total & $\begin{array}{c}\text { \% of } \\
\text { Variance }\end{array}$ & Cumulative \% & Total & $\begin{array}{c}\text { \% of } \\
\text { Variance }\end{array}$ & Cumulative \% & Total & $\begin{array}{c}\text { \% of } \\
\text { Variance }\end{array}$ & Cumulative \% \\
\hline 1 & 2.822 & 40.308 & 40.308 & 2.822 & 40.308 & 40.308 & 2.341 & 33.437 & 33.437 \\
2 & 1.426 & 20.365 & 60.673 & 1.426 & 20.365 & 60.673 & 1.641 & 23.442 & 56.880 \\
3 & .888 & 12.683 & 73.356 & .888 & 12.683 & 73.356 & 1.153 & 16.477 & 73.356 \\
4 & .659 & 9.411 & 82.767 & & & & & & \\
5 & .445 & 6.359 & 89.126 & & & & & & \\
6 & .417 & 5.962 & 95.088 & & & & & & \\
7 & .344 & 4.912 & 100.000 & & & & & & \\
\hline
\end{tabular}

The percentage variability is about $80.7 \%$ for NEM and $73.5 \%$ for SWM by using the three factor loadings. The rotation has the effect of optimizing the factor structure and one consequence for these data is that the relative importance of the three factors is equalized.

Table 6 Factor loadings after PCA varimax-rotation for both monsoons

\begin{tabular}{|l|l|l|l|l|l|l|}
\hline \multirow{2}{*}{ Factors } & \multicolumn{5}{|l|}{ NEM } & \multicolumn{3}{l|}{ SWM } \\
\cline { 2 - 7 } & PC1 & PC2 & PC3 & PC1 & PC2 & PC3 \\
\hline $\mathrm{WS}^{\mathrm{a}}$ & 0.731 & -0.421 & & 0.744 & & \\
\hline $\mathrm{RH}^{\mathrm{b}}$ & -0.891 & & & & & 0.744 \\
\hline $\mathrm{Temp}^{\mathrm{c}}$ & 0.810 & & & 0.846 & & \\
\hline $\mathrm{CO}$ & & 0.832 & & & 0.808 & \\
\hline $\mathrm{O}_{3}$ & 0.811 & & & 0.859 & & \\
\hline $\mathrm{NO}_{2}$ & & 0.919 & & & 0.866 & \\
\hline $\mathrm{SO}_{2}$ & & & 0.984 & & 0.377 & 0.743 \\
\hline
\end{tabular}

The factor scores obtained from the PCA for the NEM and SWM were displayed in Table 6. There are three principal components (PC) that take accounts for the concentration of $\mathrm{PM}_{10}$ in both NEM and SWM. For NEM, PC1 $(52.6 \%$ of the total variance) was loaded with windspeed, relative and humidity and $\mathrm{O}_{3}$ which grouped all the meteorological factors in one. $\mathrm{O}_{3}$ has shown a strong correlation with the meteorological factors [28-35] and thus, falls into the same group. The relative humidity shows a negative score which indicates increasing relative humidity brings negative contributions towards $\mathrm{PM}_{10}$ concentration as high water vapor content in the air provides washing effects which reduce the amount of particles in the atmosphere [36-37]. PC2 (16.3\% of the total variance) consist of $\mathrm{CO}$ and $\mathrm{NO}_{2}$, which points towards vehicular emissions [7], [38]. PC3 (11.7\% of total variance) was weighted with only $\mathrm{SO}_{2}$, which indicates industrial emissions and open burning [39].

A slight difference among the factors distribution was noticed in the principal components for SWM compared to the NEM. PC1 (40.3\% of total variance) was predominantly weighted by windspeed, temperature, and $\mathrm{O}_{3}$, which expressed that meteorological factors were the main contributors due to the fact that increased windspeed and temperature can cause resuspension of road dust and soil deposition [40]. PC2 of SWM (20.3\% of total variance) demonstrate the similar factors loading as the PC2 in NEM, which is $\mathrm{CO}$ and $\mathrm{NO}_{2}$ that implies vehicular emission as the possible sources. PC3 (11.7\% of total variance) are made out of relative humidity and $\mathrm{SO}_{2}$, which indicates meteorological factors and open burning sources. 


\subsection{CONCLUSION}

$\mathrm{PM}_{10}$ is the only pollutant that frequently recorded concentrations exceeding the MAAQG in the duration of the year 2001 to 2010 . The criteria pollutant of these 10 years for the Northeast monsoon (NEM), Southwest monsoon (SWM) and inter-monsoons (IM) were compared, and the results show that the concentration of pollutants reported differs significantly between the monsoon seasons. $\mathrm{PM}_{10}, \mathrm{NO}_{2}$, and $\mathrm{SO}_{2}$ are notably higher during the SWM due to the stable drier meteorological conditions that cause hindrance to dispersion and removal of the pollutants from the atmosphere. The concentration of $\mathrm{CO}$ was mainly lower during the NEM. This may be due to high precipitation frequency during the NEM, which increases the amount of hydroxyl radicals in the atmosphere that acts as the sink for $\mathrm{CO}$ and in turn reducing the levels of $\mathrm{CO}$ in the air. Principal component analysis showed that sources contributing to the $\mathrm{PM}_{10}$ concentration which is meteorological factor influences, and industrial emissions.

\section{ACKNOWLEDGEMENT}

This study was funded by Fundamental Research Grant Scheme (FRGS) FRGS/2/2013/STWN01/UMT/02/1 (VOT 59312) and Universiti Malaysia Terengganu Scholarship Scheme (BUMT). The authors also would like to thank the Air Quality Division, Malaysian Department of Environment (DOE) for the air quality data.

\section{REFERENCES}

1. J. K. Vanos, C. Hebbern, and S. Cakmak. Risk assessment for cardiovascular and respiratory mortality due to air pollution and synoptic meteorology in 10 Canadian cities. Env. Pol. 185, 322-332. (2014)

2. K.-H. Kim, E. Kabir, and S. Kabir. A review on the human health impact of airborne particulate matter. Env. Int. 74, 136-143. (2015)

3. C.F. Tsai, P.K. Yip, S.-Y. Chen, J.C. Lin, Z.-T. Yeh, L.Y. Kung, C.-Y. Wang, and Y.M. Fan. The impacts of acute carbon monoxide poisoning on the brain: Longitudinal clinical and $99 \mathrm{mTc}$ ethyl cysteinate brain SPECT characterization of patients with persistent and delayed neurological sequelae. Clin. Neurol. Neurosurg. 119, 21-7. (2014)

4. D. Landau, L. Novack, M. Yitshak-Sade, B. Sarov, I. Kloog, R. Hershkovitz, I. Grotto, and I. Karakis. Nitrogen Dioxide pollution and hazardous household environment: what impacts more congenital malformation. Chemosphere. 139, 340-8. (2015)

5. U.S. EPA. 2015. Air Quality Index (AQI) Basics. U.S. EPA, National Center for Environmental Publications (NSCEP). Retrieved on Dec 16, 2015, from http://airnow.gov/index.cfm?action=aqibasics.aqi
6. Department of Environment. A Guide to Air Pollution Index (API) Malaysia, 4th Editio. Department of Environment Malaysia. (2000)

7. M. Viana, T. a J. Kuhlbusch, X. Querol, a. Alastuey, R. M. Harrison, P. K. Hopke, W. Winiwarter, M. Vallius, S. Szidat, a. S. H. Prévôt, C. Hueglin, H. Bloemen, P. Wåhlin, R. Vecchi, a. I. Miranda, a. Kasper-Giebl, W. Maenhaut, and R. Hitzenberger. Source apportionment of particulate matter in Europe: A review of methods and results. J. Aerosol Sci. 39(10), 827-849. (2008)

8. M. S. Callén, A. Iturmendi, and J. M. López. Source apportionment of atmospheric PM2.5-bound polycyclic aromatic hydrocarbons by a PMF receptor model. Assessment of potential risk for human health. Env. Pol. 195C, 167-177. (2014)

9. S. A. Jaafar, M. T. Latif, C. W. Chian, W. S. Han, N. B. A. Wahid, I. S. Razak, M. F. Khan, and N. M. Tahir. Surfactants in the sea-surface microlayer and atmospheric aerosol around the southern region of Peninsular Malaysia. Mar. Pollut. Bull. 84(1-2), 35-43. (2014)

10. H. H. Tsai, C. S. Yuan, C. H. Hung, C. Lin, and Y. C. Lin. Influence of sea-land breezes on the temporospatial distribution of atmospheric aerosols over coastal region. J. Air Waste Manag. Assoc. 61(4), 358-376. (2011)

11. M. J. Molina and L. T. Molina. Megacities and Atmospheric Pollution. J. Air Waste Manag. Assoc. 54(6), 644-680. (2004)

12. D. K. Papanastasioua and D. Melas. Climatology and impact on air quality of sea breeze in an urban coastal environment. Int. J. Climatol. April 2008: 305-315. (2008)

13. Malaysian Meteorological Department. General Climate of Malaysia. Retrieved on December 11, 2015, from http://www.met.gov.my/web/metmalaysia/climate/gener alinformation/malaysia.

14. Department of Statistics. Population Distribution and Basic Demographic Characteristics. Dept of Statistics, Malaysia. Retrieved on December 11, 2015, from http://www.statistics.gov.my/portal/ (2011)

15. D. Voukantsis, K. Karatzas, J. Kukkonen, T. Räsänen, A. Karppinen, and M. Kolehmainen. Intercomparison of air quality data using principal component analysis and forecasting of $\mathrm{PM}_{1} 0$ and $\mathrm{PM}_{2}{ }_{5}$ concentrations using artificial neural networks, in Thessaloniki and Helsinki. Sci Total Environ. 409(7): 1266-76. (2011)

16. R. Baklouti, M. Mansouri, M. Nounou, H. Nounou, and A. Ben Hamida. Iterated robust kernel Fuzzy Principal Component Analysis and application to fault detection. J. Comput. Sci. (2015)

17. Yoshida, S., Morimoto, T., Ushio, T., Kawasaki, Z. 2007. ENSO and convective activities in Southeast Asia and western Pacific. Geophys. Res. Lett. 34, L21806 (2007)

18. Mohd Tahir et al. PM 2.5 and Associated Ionic Species in a Sub-urban Coastal Area of Kuala Terengganu, 
Southern South China Sea (Malaysia). Sains Malays. 42(8), 1065-1072. (2013)

19. N. Mohd Tahir, S. Suratman, F. T. Fong, M. S. Hamzah, and M. T. Latif. Temporal Distribution and Chemical Characterization of Atmospheric Particulate Matter in the Eastern Coast of Peninsular Malaysia Aerosol Air Qual. Res. 13, 584-595. (2013)

20. M. Z. Ibrahim, K. H. Yong, M. Ismail, and A. Albani. Spatial Analysis of Wind Potential for Malaysia. Int. J. Renew. Energy Res. 5, 201-209. (2015)

21. A. Camerlengo and M. I. Demmler. Maritime Circulation of the South China Sea: A Numerical Study. Pertanika J Sci. Tech. 4, 131-139. (1996)

22. M. Grundström, C. Hak, D. Chen, M. Hallquist, and H. Pleijel. Variation and co-variation of PM10, particle number concentration, NOx and NO2 in the urban air Relationships with wind speed, vertical temperature gradient, and weather type. Atmos. Environ. 120, 317327. (2015)

23. M. Bralic, M. Buljac, N. Peris, M. Buzuk, P. Dabic, and S. Brinic. Monthly and Seasonal Variations of NO2, $\mathrm{SO} 2$, and Black-smoke Located within the Sport District in Urban Area, City of Split, Croatia. Croatia Chemical Acta. 85(2), 139-145. (2012)

24. K. Park and T. S. Rhee. Source characterization of carbon monoxide and ozone over the Northwestern Pacific in summer 2012. Atmos. Environ. 111, 151160. (2015)

25. T. Holloway, H. Levy II, and P. Kasibhatla. Global Distribution of CO. J. Geophy. Res. 105(10), 123-147. (2000)

26. J. M. Wallace and P. V. Hobbs. Atmospheric Science: An Introductory Survey. (2006)

27. Y. P. Chua, Advanced Research Statistics (Book 5). Regression, Factor and SEM Analysis. McGraw Hill. (2009)

28. M. T. Latif, L. S. Huey, and L. Juneng. Variations of surface ozone concentration across the Klang Valley, Malaysia. Atmos. Environ. 61, 434-445. (2012)

29. A. S. Ismail, M. T. Latif, S. Z. Azmi, L. Juneng, and A. A. Jemain. Variation of Surface Ozone Recorded at the Eastern Coastal Region of the Peninsular Malaysia. Am. J. Env. Sci. 6(6), 560-569. (2010)

30. F. Ahamad, M. T. Latif, R. Tang, L. Juneng, D. Dominick, and H. Juahir. Variation of surface ozone exceedance around Klang Valley, Malaysia. Atmos. Res. 139, 116-127. (2014)

31. M. Ismail. Time-Series Analysis of Ground-Level Ozone in Muda Irrigation Scheme Area (Mada), Kedah. J. Sustainable Sci. Manag. 6(1), 79-88. (2011)

32. Y. Y. Toh, S. F. Lim, and R. von Glasow. The influence of meteorological factors and biomass burning on surface ozone concentrations at Tanah Rata, Malaysia. Atmos. Environ. 70: 435-446. (2013)

33. E. Stathopoulou, G. Mihalakakou, M. Santamouris, and H. S. Bagiorgas. On the impact of temperature on tropospheric Ozone concentration levels in urban environments. J. Earth Syst. Sci. 117(2), 227-236. (2008)

34. D. J. Rasmussen, A. M. Fiore, V. Naik, L. W. Horowitz, S. J. McGinnis, and M. G. Schultz. Surface ozonetemperature relationships in the eastern US: A monthly climatology for evaluating chemistry-climate models. Atmos. Environ. 47, 142-153. (2012)

35. T. Wang, Y. Y. Wu, T. F. Cheung, and K. S. Lam. A study of surface ozone and the relation to complex wind flow in Hong Kong. Atmos. Environ. 35(18), 32033215. (2001)

36. D. Giri, K. Murthy, and P. R. Adhikary. The Influence of Meteorological Conditions on PM 10 Concentrations in Kathmandu Valley. Int. J. Environ. Res.2 (1), 49-60. (2008)

37. M. Braniš and J. Větvička. PM10, Ambient temperature and relative humidity during the XXIX summer olympic games in Beijing: Were the athletes at risk?. Aerosol Air Qual. Res. 10(2), 102-110. (2010)

38. D. H. Stedman, G. A. Bishop, and A. Peddle. On-Road Motor Vehicle Emissions including $\mathrm{NH} 3, \mathrm{SO} 2$ and NO2. California Environmental Protection Agency. The University of Denver. (2009)

39. M.E. Luvsan, R.H. Shie, T. Purevdorj, L. Badarch, B. Baldorj, and C.C. Chan. The influence of emission sources and meteorological conditions on $\mathrm{SO} 2$ pollution in Mongolia. Atmos. Environ. 66, 542-549. (2012)

40. WHO. Health Aspects of Air Pollution with Particulate Matter, Ozone and Nitrogen Dioxide. Rep. a WHO Work. Gr. Bonn, Ger. 13-15 January 2003, no. January, p. 98,2003 . (2003) 